Jurnal KBP

Volume 1 - No. 2, September 2013

\title{
ANALISIS PENGARUH PEMBERIAN KREDIT TERHADAP PROFITABILITAS PT. BANK PEMBANGUNAN DAERAH (BPD) SUMATERA BARAT
}

\author{
Afriyeni \\ AKBP Padang \\ (afriyeni.yen@gmail.com)
}

\begin{abstract}
This study was conducted to determine the effect of credit on profitability at PT. BPD of West Sumatra. Especially during the last 5 years (2007-2011). The problem in this study is whether the credit effect on profitability ratios using measuring devices Return On Investment (ROI) and Return On Equity (ROE). To analyze the data used correlation coefficient, coefficient of determination and simple regression analysis. From the results of research conducted indicates that credit has positive influence on the measuring instrument ROI. From the results of regression testing obtained significant value of 0.036. This means a significant difference between the provision of credit to the ROI because of the significant value below the significance level $(\alpha)=0.05$. The extension of credit has a significant influence on ROE. Based on test results obtained significant regression of 0.007. This means a significant difference between the provision of credit to the return on equity because of the significant value is below the real level $(\alpha)=0.05$. From the research results are also obtained by the value of the coefficient of determination $(r 2)=0.203$ which means that $20.3 \%$ ROI which can be explained by the provision of credit and the remaining $79.7 \%$ is influenced by other factors. As for the ROE coefficient of determination ( $r 2)=0.594$ which means that 59.4\% ROE can be explained by the provision of credit and the remaining $40.6 \%$ is influenced by other factors .
\end{abstract}

Keywords : Credit, profitability, ROI, ROE

\section{PENDAHULUAN}

Profitabilitas merupakan kemampuan perusahaan untuk menghasilkan laba atau keuntungan selama periode tertentu dibandingkan dengan modal dan aktiva yang dinyatakan dalam persentase, yang merupakan hasil dari berbagai kebijaksanaan dan keputusan yang diterapkan oleh perusahaan menurut Hasibuan (2002). Untuk menilai profitabilitas suatu perusahaan ada bermacam cara tergantung pada laba yang dibandingkan dengan modal dan asset yang dimiliki.

Dalam laporan keuangan dapat dilihat tingkat profitabilitas suatu perusahaan. Profitabilitas dapat tercermin dari bagaimana efektifitas manajemen bank dalam mengelola dana yang dipercayakan kepadanya untuk dapat menghasilkan laba atau keuntungan. Apabila bank dapat meningkatkan profitabilitasnya, maka bank tidak akan mendapat kesulitan dalam membayar hutangnya. 
Bank sebagai lembaga keuangan yang melakukan penghimpunan dana dari masyarakat dan selanjutnya menyalurkan dana tersebut ke masyarakat dalam bentuk kredit. Bank dapat memberikan bermacam-macam jasa pembiayaan, bank juga dapat melayani kebutuhan masyarakat dan dunia usaha pengguna jasa kredit untuk meningkatkan kualitas kehidupan masyarakat.

Laba atau keuntungan sangat diharapkan oleh perusahaan untuk mempertahankan kelangsungan hidupnya. Salah satu cara perusahaan untuk mendapatkan keuntungan yaitu dengan memberikan kredit pada nasabahnya. Kredit sangat penting bagi profitabilitas karena dengan adanya peningkatan atau perkembangan kredit yang disalurkan setiap tahunnya, maka akan meningkatkan pula profitabilitasnya. Untuk tetap mempertahankan agar laba suatu perusahaan meningkat, maka kredit yang disalurkan harus pula ditingkatkan.

PT. Bank Pembangunan Daerah Sumatera Barat (BPD Sumbar) yang dikenal dengan sebutan Bank Nagari merupakan salah satu bank umum di Sumatera Barat yang berdiri sejak tahun 1962. Pada mulanya seluruh modal dan sahamnya dimiliki oleh pemerintah daerah, yaitu Pemerintah Propinsi dan Pemerintah Kabupaten / Kota se-Sumatera Barat.

Dalam memberikan kredit, bank harus mempunyai prinsip kehati-hatian. Kesalahan dalam memberikan kredit akan memberikan resiko yang besar bagi bank. Resiko tersebut berupa resiko tidak tertagihnya pinjaman, dan terlambatnya penerimaan pinjaman dari jadwal, sehingga menimbulkan kredit macet.

Tabel 1. Perkembangan Pemberian Kredit Dan Laba PT. BPD Sumatera Barat Tahun 2007-2011 (dalam jutaan Rp)

\begin{tabular}{|c|c|c|}
\hline Tahun & Jumlah Pemberian Kredit & Laba \\
\hline 2007 & 4.021 .052 & 109.195 \\
\hline 2008 & 5.000 .321 & 123.084 \\
\hline 2009 & 5.911 .423 & 144.345 \\
\hline 2010 & 7.116 .204 & 252.491 \\
\hline 2011 & 9.212 .042 & 246.241 \\
\hline
\end{tabular}

Sumber : PT. BPD Sumbar, 2012

Dari tabel 1 dapat diketahui bahwa jumlah pemberian kredit PT. BPD Sumbar mengalami peningkatan dari tahun ketahun yaitu dari $\mathrm{Rp}$ 4.021.052.000.000 tahun 2007 menjadi Rp 9.212.042.000.000 tahun 2011. Sedangkan jumlah laba meningkat dari tahun 2007 sampai tahun 2010, namun pada tahun 2011 menurun sebesar Rp
6.250.000.000 dari jumlah laba tahun 2011.

Tujuan penelitian ini dilakukan untuk mengetahui bagaimana pengaruh pemberian kredit terhadap profitabilitas pada PT. BPD Sumatera Barat. 


\section{TINJAUAN PUSTAKA DAN HIPOTESIS}

Menurut pasal 1 Bab 1 UU RI No. 10 Tahun 1998 tentang perubahan UU No. 7 Tahun 1992 (1999 : 9) tentang perbankan dinyatakan bahwa bank adalah badan usaha yang menghimpun dana dari masyarakat dalam bentuk simpanan dan menyalurkan kepada masyarakat dalam bentuk kredit dan bentuk lainnya dalam rangka meningkatkan taraf hidup rakyat banyak.

Berdasarkan Pasal 5 Undangundang No.10 Tahun 1998 tentang perubahan UU No. 7 tahun 1992 tentang Perbankan, terdapat dua jenis bank yaitu :

a. Bank umum

Bank umum adalah bank yang melaksanakan kegiatan usaha secara konvensional dan atau berdasarkan prinsip syariah yang dalam kegiatannya memberikan jasa dalam lalu lintas pembayaran. Sifat jasa yang diberikan adalah umum, dalam arti dapat memberikan seluruh jasa perbankan yang ada.

b. Bank Perkreditan Rakyat (BPR)

Bank Perkreditan Rakyat (BPR) adalah Bank yang melaksanakan kegiatan usaha secara konvensional atau berdasarkan prinsip syariah. Dalam kegiatannya BPR tidak memberikan jasa dalam lalu lintas pembayaran.

Menurut Munawir (1993), yang dimaksud dengan laporan keuangan adalah Dua daftar yang disusun oleh Akuntan pada akhir periode untuk suatu perusahaan. Kedua daftar itu adalah daftar neraca atau daftar posisi keuangan dan daftar pendapatan atau daftar rugi laba. Pada waktu akhir akhir ini sudah menjadi kebiasaan bagi perseroan - perseroan untuk menam- bahkan daftar ketiga yaitu daftar surplus atau daftar laba yang tak dibagikan (laba yang ditahan).

Ada beberapa alat analisa dasar yang dapat digunakan untuk menganalisa laporan keuangan. Berikut ini adalah beberapa alternatif alat analisa dasar untuk menganalisa laporan keuangan (Pramono ; 2001) yaitu:

1. Ratio Analysis

a. Rasio likuiditas, mengukur kemampuan perusahaan untuk memenuhi kewajiban jangka pendeknya, dan dapat juga digunakan untuk mengukur efisiensi penggunaan aktiva lancar.

b. Rasio solvabilitas, mengukur tingkat kemampuan untuk kreditor jangka panjang.

c. Rasio profitabilitas, mengukur kemampuan perusahaan dalam menghasilkan keuntungan.

d. Kelompok special rasio yang diminta oleh investor sebagai tambahan terhadap rasio likuiditas, hutang dan profitabilitas.

e. Rasio aliran kas (cash flow ratio), dapat mengindikasikan likuiditas, kapasitas peminjaman, atau profitabilitas.

2. Common-Size Analysis

a. Analisa vertikal membandingkan tiap bagian dengan dasar bagian tertentu dalam tahun yang sama.

b. Analisa horizontal membandingkan tiap bagian dengan bagian pada tahun dasar yang telah ditetapkan.

\section{Comparison}

Analisis trend mempelajari sejarah keuangan perusahaan untuk perbandingan. Dengan melihat trend (kecenderungan) dari rasio tertentu, dapat diketahui apakah 
rasio tersebut menurun, meningkat, atau relatif konstan.

Profitabilitas biasanya digunakan oleh perusahaan untuk menunjukkan kemampuan perusahaan dalam memperoleh laba dalam hubungannya dengan penjualan, total aktiva, maupun modal sendiri.

Ada beberapa pengertian tentang profitabilitas :

1. Siamat (1995), profitabilitas adalah kemampuan perusahaan untuk menghasilkan laba dari seluruh penggunaan dana yang ditanamkan dalam bank.

2. Weston (1994:92) mengemu-kakan profitabilitas adalah kemampuan perusahaan untuk memperoleh laba dari seluruh penggunaaan dana yang ditanamkan dalam perusahaan. Rasio untuk mengukur aktivitas manajemen yang ditunjukan oleh laba yang dihasilkan dari perusahaan..

Dari definisi tersebut, maka dapat disimpulkan bahwa profitabilitas itu merupakan kemampuan perusahaan untuk menghasilkan laba atau keuntungan selama periode tertentu dibandingkan dengan modal dan aktiva yang dinyatakan dalam persentase yang merupakan hasil lebih dari berbagai kebijaksanaan dan keputusan yang diterapkan oleh perusahaan.

Untuk menilai profitabilitas suatu perusahaan ada bermacam-macam cara, tergantung pada laba yang dibandingkan dengan modal dan aset yang dimiliki. Apakah yang dibandingkan itu laba yang berasal dari operasi atau laba netto sesudah pajak dengan aktiva operasi, atau laba netto sebelum pajak dibanding dengan keseluruhan aktiva atau dengan modal yang dimiliki.

Laba atau keuntungan diperlukan oleh perusahaan, agar perusahaan tersebut dapat mempertahankan kelangsungan hidupnya serta mengembangkan dirinya dan menginvestasikan kembali sebagian atau seluruh laba tersebut kedalam perusahaan. Tapi pada umumnya masalah profitabilitas bagi perusahaan lebih penting dari pada masalah laba, karena laba yang besar belumlah merupakan ukuran bahwa perusahaan tersebut telah bekerja dengan efisien. Efisien baru diketahui dengan membandingkan laba yang diperoleh dengan yang menghasilkan laba tersebut. Hal yang harus diperhatikan perusahaan adalah tidak hanya usaha untuk memperbesar laba, tetapi usaha untuk mempertinggi profitabilitas.

Pengukuran profitabilitas yang terdapat pada dunia perbankan digunakan untuk mengukur produktifitas tingkat efisien usaha yang akan dicapai oleh perusahaan yang bersangkutan. Dalam hal ini terdapat beberapa pendapat mengatakan bahwa yang penting dalam perusahaan adalah maksimum profitabilitas yaitu kemampuan suatu perusahaan untuk menghasilkan laba setelah disbandingkan dengan aktiva atau modal yang menghasilkan laba tersebut dalam periode tertentu.

Rasio yang digunakan dalam mengukur profitabilitas perusahaan menurut Darsono (2005 : 56 ) :

1. Return On Equity (ROE)

Merupakan rasio yang dipakai untuk mengukur kemampuan perusahaan dengan seluruh dana yang tertanam dalam modal sendiri (ekuitas) dalam memperoleh keuntungan.

$$
\mathrm{ROE}=\frac{\text { Laba Bersih }}{\text { Equity }} \times 100 \%
$$

Rasio ini menunjukkan kesuksesan manajemen dalam memaksimalkan tingkat kembalian pada pemegang saham. Semakin tinggi rasio ini akan 
semakin baik karena memberikan tingkat kembalian yang lebih besar pada pemegang saham.

2. Return On Investment (ROI) Merupakan salah satu bentuk dari profitabilitas yang digunakan pimpinan perusahaan untuk mengukur efisiensi atau efektivitas dari keseluruhan operasi perusahaan. Efisiensi menunjukan perbandingan keuntungan yang diperoleh dari operasi perusahaan dengan jumlah investasi atau aktiva yang digunakan untuk menghasilkan keuntungan dari hasil operasi perusahaan tersebut.

$$
\text { ROI }=\frac{\text { Laba Bersih }}{\text { Total Aktiva }} \times 100 \%
$$

Keunggulan dari pengunaan rasio ROI adalah sebagai berikut:

1. ROI merupakan pengukuran yang komprehensif dimana seluruhnya mempengaruhi laporan keuangan yang tercermin dari rasio ini.

2. ROI mudah dihitung, dipahami dan sangat berarti dalam nilai absolut

3. ROI merupakan denominator yang dapat diterapkan pada setiap organisasi yang bertanggung jawab terhadap profitabilitas dan unit usaha.

Menurut Undang-undang No. 10 tahun 1998 tentang perubahan UndangUndang No. 7 tahun 1992 Tentang Perbankan pasal 1 merumuskan pengertian kredit adalah penyedian uang atau tagihan yang dapat dipersamakan dengan itu, berdasarkan persetujuan atau kesepakatan pinjam meminjam antara bank dengan pihak lain yang mewajibkan pihak peminjam melunasi hutangnya setelah jangka waktu tertentu dengan jumlah bunga, imbalan atau pembagian hasil keuntungan. Dari definisi yang terdapat dalam undang-undang dapat disimpulkan bahwa unsur-unsur kredit berupa kepercayaan, waktu, risiko dan prestasi. Pemberian suatu fasilitas kredit mempunyai beberapa tujuan yang hendak dicapai yang tentunya targantung dari tujuan bank itu sendiri. Tujuan pemberian kredit juga tidak akan terlepas dari misi bank tersebut didirikan.

Menurut Sugiharto ( $2006: 289$ ), kriteria penilaian yang umum dan harus dilakukan oleh bank untuk mendapatkan nasabah yang benarbenar layak untuk diberikan, dilakukan dengan analisis 6C.

Penilaian dengan analisis $6 \mathrm{C}$ adalah sebagai berikut:

\section{Character}

Adalah keadaan watak/sifat dari nasabah, baik dalam kehidupan pribadi maupun dalam lingkungan usaha. Kegunaan dari penilaian terhadap karakter ini adalah untuk mengetahui sampai sejauh mana keinginan nasabah untuk memenuhi kewajibannya sesuai dengan perjanjian yang telah ditetapkan.

2. Capacity

Adalah kemampuan yang dimiliki calon nasabah dalam menjalankan usahanya guna memperoleh laba yang diharapkan. Kegunaan dari penilaian ini adalah untuk mengetahui / mengukur sampai sejauh mana calon nasabah mampu untuk mengembalikan atau melunasi utang - utangnya secara tepat waktu dari usaha yang diperolehnya.

3. Capital

Adalah jumlah dana / modal sendiri yang dimiliki oleh calon nasabah. Semakin besar modal sendiri dalam perusahaan, tentu semakin tinggi kesungguhan calon nasabah dalam menjalankan usahanya dan bank akan merasa 
lebih yakin dalam memberikan kredit.

\section{Condition of Economy}

Adalah situasi dan kondisi politik, sosial, ekonomi, budaya, yang mempengaruhi keadaan perekonomian pada suatu saat yang kemungkinannya mempengaruhi kelancaran perusahaan calon debitur.

5. Collateral

Adalah barang - barang yang diserahkan nasabah sebagai agunan terhadap kredit yang diterimanya. Collateral tersebut harus dinilai oleh bank untuk mengetahui sejauh mana risiko kewajiban finansial nasabah kepada bank. Penilaian terhadap jaminan ini meliputi jenis, lokasi, buku pemilikan, dan status hukumnya.

\section{Constraint}

Adalah batasan dan hambatan yang tidak memungkinkan suatu bisnis untuk dilaksanakan pada tempat tertentu misalkannya pendirian suatu usaha pompa bensin yang disekitarnya banyak bengkel las atau pembakaran batu bata.

Sumber dana merupakan yang sangat penting bagi manager keuangan ataupun bagi calon kreditur serta bagi bank yang menilai permintaan kredit yang diajukan kepadanya. Sumber dana ini penting juga dalam mengelolanya, menghimpun atau menggunakan data yang dimilikinya. Dimana dalam mengelola dan menghimpun dana tersebut, harus mengenal sumbersumber yang ada, khususnya sumber dana yang berasal dari masyarakat. Dari sumber dana yang berhasil dihimpun oleh bank tersebut diharapkan dapat memperoleh profitabilitas yang dikehendaki dengan cara mengalokasikan dana tersebut kepada masyarakat dalam bentuk kredit.
Sebagai lembaga keuangan bank memiliki usaha pokok dalam menghimpun dana dari masyarakat dan menyalurkan kembali kepada masyarakat untuk jangka waktu tertentu. Dalam usaha menghimpun dana tersebut, tentu bank harus mengenal sumber-sumber dana yang berada dalam bentuk yang berbedabeda pula. Dalam garis besarnya sumber dana bank ada tiga (Suyatno, 1997 : 29) adalah sebagai berikut :

1. Dana yang bersumber dari bank itu sendiri

Dana-dana yang berasal dari bank itu sendiri biasanya berbentuk modal sektor cadangan dan keuntungan yang belum di bagikan. Modal yang berasal dari pemegang saham yang dapat dikatakan bersifat tetap dalam arti tidak mudah untuk ditarik begitu saja oleh penyetornya. Sedangkan cadangan dan keuntungan yang belum di bagikan dapat digunakan sebagai modal kerja.

2. Dana yang berasal dari Masyarakat

Diperoleh dari sumber ini digunakan untuk membiayai dan membayar transaksi-transaksi tertentu. Perolehan dari sumber dana ini dapat diperoleh dari :

a. Kredit likuiditas dari Bank Indonesia yaitu kredit yang diberikan oleh Bank Indonesia kepada bank yang mengalami kesulitan likuiditas. Kredit likuiditas ini juga di berikan kepada pembiayaan sektor-sektor tertentu.

b. Pinjaman antar bank (call money) yaitu dana dalam rupiah yang dipinjam oleh bank dari bank lain paling lama tujuh hari yang setiap waktu dapat ditarik kembali oleh bank yang meminjamkan tanpa dikenakan suatu pembebanan.

c. Pinjaman dari bank-bank luar negeri yaitu merupakan pinjaman 
yang diperoleh oleh perbankan dari pihak luar negeri.

d. Surat berharga pasar uang (SBPU) yaitu surat-surat berharga jangka pendek yang dapat diperjualbelikan secara diskonto dengan Bank Indonesia dan lembaga keuangan lainnya ditujukan oleh Bank Indonesia.

Penelitian yang dilakukan oleh Oktavemi (2005) dengan Judul Pengaruh Pemberian Kredit Terhadap Laba Pada PT. Bank Perkreditan Rakyat (BPR) Ophir.Penelitian ini mengunakan rasio rentabilitas. Hasil penelitian menunjukkan korelasi mendekati 1, yang berarti hubungan antara kedua variabel adalah kuat dan posifif. Dimana peningkatan jumlah kredit yang diberikan kepada masyarakat diikuti dengan peningkatan laba.

Penelitian yang dilakukan oleh Siskawati (2006) dengan judul Analisis Realisasi Kredit Terhadap Profitabilitas pada Bank Perkreditan Rakyat (BPR) Padang Tarap. Penelitian ini dilakukan Kerangka Konseptual untuk menilai jumlah kredit yang diberikan dengan pendapatan /profitabilitas setiap tahunnya. Penilaian yang dilakukan menggunakan rasio ROA dan LDR. Hasil penelitian ini dinilai sehat, karena batas maksimum LDR sehat suatu bank adalah $110 \%$. Sehingga dinyatakan BPR Padang Tarap ini mampu dalam membayar kembali penarikan dana yang dilakukan deposan dengan menggunakan kredit yang diberikan. Dari faktor ROA dinilai cukup efisien karena nilai ROA yang diperoleh tahun 2001-2005 berkisar 6,59\% - 8,51\% dengan pinjaman dari asset semuanya $90 \%$.

Dalam penelitian ini menggunakan rasio ROI dan ROE untuk mengukur profitabilitas, karena pada penelitian terdahulu, hanya menggunakan rasio rentabilitas, LDR, dan ROA. Dalam hal ini, peneliti juga ingin membuktikan bahwa pemberian kredit berpengaruh signifikan terhadap profitabilitas.

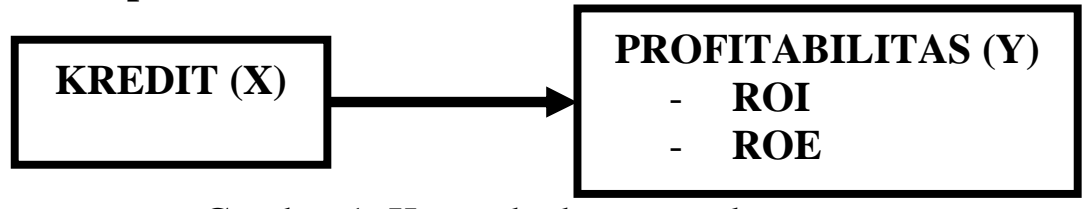

Gambar 1. Kerangka konseptual

\section{Hipotesis}

H1 $_{1}$ : Pemberian kredit berpengaruh signifikan terhadap Return on Investment (ROI) PT. Bank Pembangunan Daerah (BPD) Sumbar.

$\mathbf{H}_{2}$ : Pemberian kredit berpengaruh signifikan terhadap Return on Equity (ROE) PT. Bank Pembangunan Daerah (BPD) Sumbar.

\section{METODE PENELITIAN}

Penelitian ini dilakukan pada PT. BPD Sumatera Bart yang beralamat di Jl. Pemuda No. 21 Padang Provinsi Sumatera Barat.Penelitian ini dilakukan pada PT. BPD Sumbar. Penelitian ini dilakukan untuk melihat pengaruh pemberian kredit terhadap profitabilitas dengan menggunakan analisa rasio ROI dan ROE periode tahun 2007-2011. Jenis penelitian ini termasuk dalam penelitian kausatif, yang bertujuan untuk menentukan hubungan sebab akibat dari suatu 
fenomena atau masalah yang diteliti untuk melihat pengaruh variabel bebas terhadap variabel terikat.

\section{Definisi dan Operasional Variabel Variabel Independen}

Variabel independen adalah variabel yang secara sendiri-sendiri atau bersama-sama mempengaruhi variabel dependen. Dalam penelitian ini yang menjadi variabel independen adalah pemberian kredit.

\section{Variabel Dependen}

Variabel dependen adalah yang variabel yang dipengaruhi oleh variabel independen. Dalam penelitian ini yang menjadi variabel dependen adalah profitabilitas. Yaitu Kemampuan suatu perusahaan untuk menghasilkan laba selama periode tertentu yang ditunjuk dari perbandingan antara laba dengan modal yang menghasilkan laba tersebut. Cara untuk menilai profitabilitas suatu perusahaan adalah bermacam-macam. Adapun yang dipakai penulis untuk mencari tingkat profitabilitas perusahaan menurut Darsono (2005: 56) yaitu :

1. Return On Equity (ROE)

$$
R O E=\frac{\text { lababersih }}{\bmod \text { alsendiri }} \times 100 \%
$$

\section{Return On Investment (ROI)}

$$
R O I=\frac{\text { lababersih }}{\text { Totalaktiva }} \times 100 \%
$$

Untuk menganalisis data dan pengujian hipotesis, penelitian ini menggunakan beberapa metode antara lain :

\section{Koefisien Korelasi}

Koefisien korelasi digunakan untuk mengukur keeratan hubungan antara dua variabel. Dalam penelitian ini koefisien korelasinya untuk mencari hubungan pemberian kredit dengan tingkat profitabilitas.

\section{Koefisien Determinasi}

Koefisien determinasi $\left(\mathrm{R}^{2}\right)$ menurut Nugroho (2005:50) bertujuan untuk mengetahui seberapa besar kemampuan variabel independen menjelaskan variabel dependen. Dalam output SPSS, koefisien determinasi terletak pada tabel Model Summary ${ }^{b}$ dan tertulis $R$ Square.

3. Analisis Regresi Sederhana

Analisa regresi sederhana adalah suatu teknik statistik yang digunakan untuk mengetahui seberapa besar pengaruh variabel bebas terhadap variabel terikat (Kuncoro,2003). Yang digunakan untuk mencari pengaruh pemberian kredit terhadap tingkat profitabilitas dengan mengukur besarnya perubahan variabel dependen tingkat profitabilitas dengan variabel independen pemberian kredit. Rumus yang digunakan sebagai berikut :

Dimana :

$$
\mathrm{Y}=\mathrm{a}+\mathrm{bx}
$$

$$
\begin{aligned}
Y & =\text { Profitabilitas. } \\
X & =\text { Pemberian Kredit } \\
a & =\text { Konstanta. } \\
b & =\text { Koefisien Regresi. }
\end{aligned}
$$

Variabel independen adalah variabel yang secara sendiri-sendiri atau bersama-sama mempengaruhi variabel dependen. Dalam penelitian ini yang menjadi variabel independen adalah pemberian kredit. Variabel dependen adalah profitabilitas, yaitu kemampuan suatu perusahaan untuk menghasilkan laba selama periode tertentu yang ditunjuk dari perbandingan antara laba dengan modal yang menghasilkan laba tersebut.

\section{HASIL DAN PEMBAHASAN}

Berikut ini disajikan hasil penelitian:

a. Perkembangan Pemberian Kredit

Pada tabel 2, disajikan perkembangan pemberian kredit pada PT. BPD Sumbar tahun 2007 sampai dengan 2011. 
Tabel 2.

Perkembangan Pemberian Kredit PT. BPD Sumbar Tahun 2007 - 2011

\begin{tabular}{|c|c|c|}
\hline Tahun & $\begin{array}{c}\text { Pemberian Kredit } \\
\text { (Dalam jutaan Rupiah) }\end{array}$ & $\begin{array}{c}\text { Pertumbuhan } \\
(\%)\end{array}$ \\
\hline 2007 & 4.021 .052 & - \\
\hline 2008 & 5.000 .321 & 24,35 \\
\hline 2009 & 5.911 .423 & 18,22 \\
\hline 2010 & 7.116 .204 & 20,38 \\
\hline 2011 & 9.212 .042 & 29,45 \\
\hline
\end{tabular}

Sumber : PT. BPD Sumbar, 2012

Dari tabel 2 dapat dilihat total penyaluran kredit sampai dengan akhir tahun 2011 telah mencapai Rp 9,21 triliun atau meningkat $\mathrm{Rp} 2,09$ triliun dengan pertumbuhan $29,45 \%$ dari posisi akhir tahun 2010 yang berjumlah Rp 7,12 triliun. Dari tabel diatas juga terlihat, pertumbuhan pemberian kredit yang berfluktuasi dari tahun 2007 sampai tahun 2011 dengan tingkat pertumbuhan terendah pada tahun 2009 sebesar $18,22 \%$

b. Perkembangan Profitabilitas

1) Perkembangan ROI ( Return On Investment )

Pada tabel 3 berikut ini penulis sajikan hasil perhitungan Return On Investment (ROI) pada PT. BPD Sumbar dari tahun 2007 sampai tahun 2011:

Tabel 3.

Return on Investment (ROI) PT. BPD Sumbar Tahun 2007 - 2011

\begin{tabular}{|c|c|c|c|}
\hline Tahun & $\begin{array}{c}\text { Laba Bersih } \\
\text { (Dalam jutaan Rupiah) }\end{array}$ & $\begin{array}{c}\text { Total Aktiva } \\
\text { (Dalam jutaan Rupiah) }\end{array}$ & $\begin{array}{c}\text { ROI } \\
(\%)\end{array}$ \\
\hline 2007 & 109.195 & 6.404 .115 & 1,71 \\
\hline 2008 & 123.084 & 6.811 .396 & 1,81 \\
\hline 2009 & 144.345 & 8.139 .512 & 1,77 \\
\hline 2010 & 252.491 & 10.308 .656 & 2,45 \\
\hline 2011 & 246.241 & 12.895 .959 & 1,91 \\
\hline
\end{tabular}

Sumber : PT. BPD Sumbar, 2012

Dari tabel 3 terlihat bahwa Return on Investment (ROI) pada PT. BPD Sumbar diatas menggambarkan bahwa bank cukup efisien dalam menghasilkan laba yang lebih maksimal dari tahun 2007 sampai dengan tahun 2011. Walaupun Return on Investment (ROI) ada yang mengalami kenaikan dan penurunan, namun hal ini tidak memberikan dampak buruk bagi bank karena Return on Investment (ROI) PT. BPD Sumbar menunjukan tanda positif yang berarti suatu bank tersebut mampu untuk menghasilkan laba. Return on Investment (ROI) dibuat untuk mengetahui kemampuan asset atau aktiva bank dalam menghasilkan laba bersih pada setiap tahunnya apakah mengalami kenaikan atau penurunan dan juga untuk mengetahui apakah telah terjadi efisiensi dalam penggunaan modal dalam suatu bank.

2) Perkembangan ROE (Return on Equity)

Berikut ini disajikan tabel 4. yang memperlihatkan Return on Equity 
(ROE) PT. BPD Sumbar tahun 2007

sampai tahun 2011 :

Tabel 4.

Return on Equity (ROE) PT. BPD SumbarTahun 2007 - 2011

\begin{tabular}{|c|c|c|c|}
\hline Tahun & $\begin{array}{c}\text { Laba Bersih } \\
\text { (Dalam jutaan Rupiah) }\end{array}$ & $\begin{array}{c}\text { Equity } \\
\text { (Dalam jutaan Rupiah) }\end{array}$ & $\begin{array}{c}\text { ROE } \\
(\%)\end{array}$ \\
\hline 2007 & 109.195 & 625.262 & 17,46 \\
\hline 2008 & 123.084 & 694.408 & 17,73 \\
\hline 2009 & 144.345 & 749.293 & 19,26 \\
\hline 2010 & 252.491 & 931.176 & 27,12 \\
\hline 2011 & 246.241 & 1.033 .130 & 23,83 \\
\hline
\end{tabular}

Sumber : PT. BPD Sumbar, 2012

Dari tabel 4. memperlihatkan Return on Equity (ROE) PT. BPD Sumbar mengalami kenaikan dari tahun 2007 sampai dengan tahun 2010 dan menurun pada tahun 2011. Hal ini terjadi karena peningkatan ekuitas sejak tahun 2010 yang cukup tinggi. Peningkatan Return on Equity (ROE) yang terjadi pada PT. BPD Sumbar memberikan dampak yang baik bagi bank karena Return on Equity (ROE) PT. BPD Sumbar menunjukan tanda positif yang berarti suatu bank tersebut mampu untuk menghasilkan laba. Analisis Return on Equity (ROE) dibuat untuk mengetahui seberapa besar kemampuan modal sendiri dalam menghasilkan laba bersih pada setiap tahunnya apakah mengalami kenaikan atau penurunan.

\section{Pengaruh Pemberian Kredit terhadap Profitabilitas}

Berikut ini disajikan pengaruh pemberian kredit terhadap return on investment:
a. Pengaruh pemberian kredit terhadap return on investment (ROI)

Tabel 5.

Tingkat Pemberian Kredit dan Return on Investment (ROI) PT. BPD Sumbar Tahun 2007 - 2011

\begin{tabular}{|c|c|c|}
\hline Tahun & $\begin{array}{c}\text { Pemberian Kredit } \\
(\mathrm{Rp} 000.000)\end{array}$ & $\begin{array}{c}\text { ROI } \\
(\%)\end{array}$ \\
\hline 2007 & 4.021 .052 & 1,71 \\
\hline 2008 & 5.000 .321 & 1,81 \\
\hline 2009 & 5.911 .423 & 1,77 \\
\hline 2010 & 7.116 .204 & 2,45 \\
\hline 2011 & 9.212 .042 & 1,91 \\
\hline
\end{tabular}

Sumber : PT. BPD Sumbar, 2012

Berdasarkan tabel 5, dapat dilihat, apabila dihubungkan kedua variabel tersebut yakni pemberian kredit dan return on Investment (ROI), maka akan dapat diketahui apakah pemberian kredit akan mempengaruhi return on Investment (ROI). Untuk menjelaskan hal tersebut digunakan persamaan regresi yaitu : $\mathrm{Y}=\mathrm{a}+\mathrm{b} \mathrm{X}$, dimana $\mathrm{Y}$ merupakan return on Investment (ROI), $\mathrm{X}$ merupakan pemberian kredit, sedangkan a dan $b$ 
merupakan koefisien regresi sederhana. Berdasarkan data tersebut, nilai yang diperoleh dari hasil printout komputer dari program SPSS 16 menunjukan persamaan sebagai berikut :

$\mathrm{Y}=1,510+0,007 \mathrm{X}$

Dari perhitungan regresi tersebut, didapat nilai $\mathrm{a}=1,510$ yang berarti bahwa pada saat pemberian kredit (X) konstan maka return on investment $(\mathrm{Y})$ sebesar 1,510. Sedangkan nilai $b=$ 0,007 yang berarti jika pemberian kredit meningkat maka return on investment (Y) akan meningkat sebesar 0,007 satuan.

Untuk menguji hasil regresi diatas apakah signifikan atau tidak signifikan maka dapat dilihat dari koefisien korelasi dan determinasi serta tabel coefisien signifikan. Dari hasil perhitungan, dapat diketahui bahwa nilai $r=0,451$, hal ini menunjukkan hubungan yang lemah di antara return on investment (ROI) dengan pemberian kredit. Arah hubungan yang positif menunjukkan semakin tinggi pemberian kredit maka return on investment (ROI) akan naik. Sedangkan dilihat dari koefisien determinasi $\left(\mathrm{r}^{2}\right)=$ 0,203 yang berarti bahwa 20,3\% yang dapat diterangkan/diperhitungkan dalam pemberian kredit dan sisanya $79,7 \%$ dipengaruhi oleh faktor lain seperti faktor eksternal bank seperti keadaan ekonomi yang tidak stabil sehingga bank harus lebih berhati-hati dalam memberikan kredit kepada masyarakat. Berdasarkan hasil printout program SPPS dengan menggunakan taraf nyata $(\alpha)=0,05$, maka diperoleh signifikan sebesar 0,446. Hal ini berarti tidak terdapat pengaruh yang signifikan antara pemberian kredit terhadap return on investment (ROI) karena nilai signifikan berada diatas taraf nyata.
b. Pengaruh pemberian kredit terhadap return on Equity (ROE)

Tabel 6.

Tingkat Pemberian Kredit dan Return on Equity (ROE)

PT. BPD Sumbar Tahun 2007 - 2011

\begin{tabular}{|c|c|c|}
\hline Tahun & Pemberian Kredit $(\mathrm{Rp} 000.000)$ & ROE ( \% ) \\
\hline 2007 & 4.021 .052 & 17,46 \\
\hline 2008 & 5.000 .321 & 17,73 \\
\hline 2009 & 5.911 .423 & 19,26 \\
\hline 2010 & 7.116 .204 & 27,12 \\
\hline 2011 & 4.021 .052 & 23,83 \\
\hline
\end{tabular}

Sumber : PT. BPD Sumbar, 2012

Berdasarkan tabel 6, dapat dlihat, apabila dihubungkan kedua variabel yakni pemberian kredit dan return on equity (ROE), maka akan dapat diketahui apakah pemberian kredit akan mempengaruhi return on equity (ROE). Untuk menjelaskan hal tersebut digunakan persamaan regresi yaitu : $\mathrm{Y}=$ $\mathrm{a}+\mathrm{b} \mathrm{X}$, dimana $\mathrm{Y}$ merupakan return on equity (ROE), $\mathrm{X}$ merupakan pemberian kredit, sedangkan a dan $\mathrm{b}$ merupakan koefisien regresi sederhana. Berdasarkan data tersebut, nilai yang diperoleh dari hasil printout komputer dari program SPSS 16 menunjukan persamaan sebagai berikut:

$\mathrm{Y}=10,930+0,002 \mathrm{X}$

Dari perhitungan regresi tersebut, didapat nilai $a=10,930$ yang berarti bahwa pada saat pemberian kredit (X) konstan, maka return on equity (Y) 
sebesar 10,930. Sedangkan nilai $b=$ 0,002 yang berarti jika pemberian kredit meningkat, maka return on equity (Y) akan meningkat sebesar 0,002 satuan.

Untuk menguji hasil regresi diatas apakah signifikan atau tidak signifikan maka, dapat dilihat dari koefisien korelasi dan determinasi serta tabel koefisien signifikan. Dari hasil perhitungan dapat diketahui bahwa nilai korelasi sebesar 0,771 , hal ini menunjukan hubungan yang kuat (mendekati 1) di antara return on equity (ROE) dengan pemberian kredit. Sedangkan dilihat dari koefisien determinasi $\left(r^{2}\right)=0,594$ yang berarti bahwa $59,4 \%$ yang dapat diterangkan/diperhitungkan dalam pemberian kredit dan sisanya 40,6\% dipengaruhi oleh faktor lain seperti faktor eksternal bank seperti keadaan ekonomi yang tidak stabil sehingga bank harus lebih berhati-hati dalam memberikan kredit kepada masyarakat. Berdasarkan hasil printout program SPPS dengan menggunakan taraf nyata $(\alpha)=0,05$, maka diperoleh signifikan sebesar 0,127 . Hal ini berarti tidak terdapat pengaruh yang signifikan antara pemberian kredit terhadap return on equity (ROE) karena nilai signifikan berada diatas taraf nyata.

\section{SIMPULAN DAN IMPLIKASI PENELITIAN \\ Simpulan}

Berdasarkan hasil penelitian, diperoleh simpulan sebagai berikut :

a. Dilihat dari pertumbuhan pemberian kredit PT. BPD Sumbar setiap tahun terus meningkat, ini menunjukan perkembangan yang baik terhadap perusahaan. Semakin meningkat pemberian kredit oleh bank, maka semakin meningkat laba bank tersebut. b. Dari tahun 2007 sampai dengan 2011 return on investmen (ROI) pada PT. BPD Sumbar mengalami kenaikan dan penurunan. Sedangkan return on equity (ROE) pada PT. BPD Sumbar mengalami kenaikan yang cukup tinggi, hal ini terjadi karena peningkatan laba yang cukup tinggi.

c. Dari hasil perhitungan diperoleh nilai $\mathrm{r}=0,451$, hal ini menunjukkan hubungan yang lemah di antara return on investment (ROI) dengan pemberian kredit. Arah hubungan yang positif menunjukkan semakin tinggi pemberian kredit maka return on investment (ROI) akan naik. Sedangkan dilihat dari koefisien determinasi $\left(\mathrm{r}^{2}\right)=0,203$ yang berarti bahwa $20,3 \%$ yang dapat diterangkan/diperhitungkan dalam pemberian kredit dan sisanya 79,7\% dipengaruhi oleh faktor lain seperti faktor eksternal bank seperti keadaan ekonomi yang tidak stabil sehingga bank harus lebih berhatihati dalam memberikan kredit kepada masyarakat. Berdasarkan hasil printout program SPPS dengan menggunakan taraf nyata $(\alpha)=0,05$ maka diperoleh signifikan sebesar 0,446. Hal ini berarti tidak terdapat pengaruh yang signifikan antara pemberian kredit terhadap return on investment (ROI) karena nilai signifikan berada diatas taraf nyata.

d. Dari hasil perhitungan diperoleh nilai korelasi sebesar 0,771 , hal ini menunjukan hubungan yang kuat (mendekati 1) di antara return on equity (ROE) dengan pemberian kredit. Sedangkan dilihat dari koefisien determinasi $\left(r^{2}\right)=0,594$ yang berarti bahwa $59,4 \%$ yang dapat diterangkan/diperhitungkan dalam pemberian kredit dan sisanya $40,6 \%$ dipengaruhi oleh faktor lain seperti faktor eksternal bank seperti 
keadaan ekonomi yang tidak stabil sehingga bank harus lebih berhatihati dalam memberikan kredit kepada masyarakat. Berdasarkan hasil printout program SPPS dengan menggunakan taraf nyata $(\alpha)=0,05$, maka diperoleh signifikan sebesar 0,127 . Hal ini berarti tidak terdapat pengaruh yang signifikan antara pemberian kredit terhadap return on equity (ROE) karena nilai signifikan berada diatas taraf nyata.

\section{Implikasi Penelitian}

Implikasi dari penelitian ini terhadap perusahaan sebagai berikut:

a. PT. BPD Sumbar lebih meningkatkan pemberian kredit kepada masyarakat agar pendapatan bunga kredit yang merupakan sumber utama penghasilan dari PT. BPD Sumbar dapat dijadikan sebagai sumber profitabilitas.

b. Pengaruh pemberian kredit terhadap profitabilitas dilihat dari return on investment (ROI) dan return on equity (ROE) yang terdapat pada PT. BPD Sumbar bersifat positif. Pada masa yang akan datang perusahaan harus meningkatkan rasio profitabilitas (ROI dan ROE) yaitu dengan meningkatkan penggunaan dana atau modal kerja untuk kegiatan pemberian kredit dan menekan biaya operasi sehingga perusahaan akan memperoleh laba yang besar.

\section{DAFTAR PUSTAKA}

Darsono, MBA, Akt. 2005. Laporan Keuangan, Andi. Yogjakarta.

Dendawijaya, Lukman, MM. 2001. Manajemen Perbankan, Ghalia Indonesia, Jakarta
Gill, James.O. 2005. Memahami Laporan Keuangan. Jakarta : Penerbit PPM

Hasibuan, Melayu. 2002, Dasar-dasar Perbankan, Penerbit Bumi Aksara, Cetakan

Kedua, Jakarta.

Kasmir, SE, MM. 2000, Bank dan Lembaga Keuangan Lainnya, Jakarta. 2002, Dasar - Dasar Perbankan, PT. Raja Grafindo Persada, Jakarta

Kuncoro, M. 2003. Metode Riset Untuk Bisnis dan Ekonomi, Bagaimana Meneliti dan Menulis Tesis, Erlangga, Jakarta.

Muljono,Teguh, Pudjo. 1994, Manajemen Perbankan komersial, BPFE, Yogjakarta.

Munawir.1993. Analisa Laporan Keuangan, Liberty, Yogjakarta.

Sekaran, U. (2003). Research Methods for Bussines a Skill Building Approach. Four Edition. John Willey and Son, inc.

Siamad.1995. Dasar-dasar Manajemen Keuangan, Ananda, Yogjakarta.

Sugiharto, SE, MBA. 2006, Credit Management Handbook, PT. Raja Grafindo.Persada, Jakarta

Sugiyarso. 2005. Manajemen Keuangan, Yogjakarta.

Suyatno. 1997. Kelembagaan Perbankan, BPFE, Yogjakarta.

Weston J. Fred dan E.F Brighman. 1994. Dasar-dasar Manajemen Keuangan. Edisi 9 Erlangga, Jakarta.

Undang-undang Perbankan No.10 tahun 1998 Tentang Perbankan. 1999. Sinar Grafika, Jakarta.

www.bi.go.id. Laporan Keuangan Perbankan 